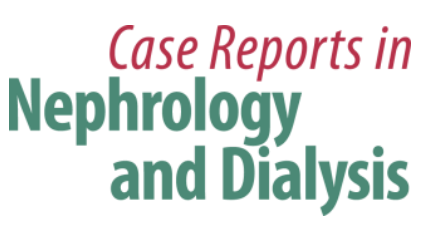

Case Rep Nephrol Dial 2018;8:178-181

DOI: 10.1159/000492614

Published online: August 31, 2018

(C) 2018 The Author(s)

Published by S. Karger AG, Basel

www.karger.com/cnd

This article is licensed under the Creative Commons Attribution-NonCommercial 4.0 International License (CC BY-NC) (http://www.karger.com/Services/OpenAccessLicense). Usage and distribution for commercial purposes requires written permission.

\title{
Minimal Change Nephrotic Syndrome Relapse after 52 Years of Remission: A Case Report
}

\author{
Hideaki Yamabe ${ }^{a}$ Mitsuaki Kaizuka $^{a}$ Satoru Tsunoda ${ }^{a}$ \\ Michiko Shimadab \\ ${ }^{a}$ EST Clinic, Hirosaki, Japan; ${ }^{b}$ Department of Nephrology, Hirosaki University Hospital, \\ Hirosaki, Japan
}

\section{Keywords}

Minimal change nephrotic syndrome $\cdot$ Relapse

\begin{abstract}
Minimal change nephrotic syndrome (MCNS) is the most common cause of nephrotic syndrome in children and can also present in adults. Corticosteroids generally induce remission of MCNS, and relapses are common after reduction or discontinuation of corticosteroids. We experienced a rare case of steroid-sensitive MCNS where the patient relapsed after 52 years of remission. The patient was a 61-year-old Japanese male who visited our clinic for an edema of the lower extremities which had already persisted for a few days. Laboratory testing showed massive urinary protein and low serum total protein and albumin levels. Therefore, he was diagnosed with nephrotic syndrome. He had a history of nephrotic syndrome that initially developed when he was 5 years old. Although corticosteroids reduced the urinary protein level, frequent relapses occurred when their doses were reduced, or when they were discontinued. He had previously experienced a relapse when he was 9 years old. For his current condition, treatment with corticosteroids and diuretics for 1 week reduced his edema and proteinuria. We suspected that this is a case of MCNS and that the present event is a relapse. Thus, we concluded that this is a very rare case of steroid-sensitive nephrotic syndrome that relapsed after 52 years of remission.

(C) 2018 The Author(s)

Published by S. Karger AG, Basel
\end{abstract}




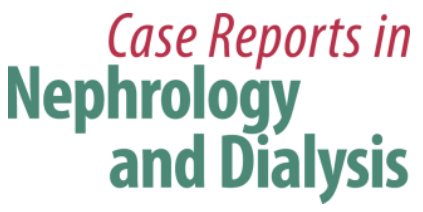

Case Rep Nephrol Dial 2018;8:178-181

DOI: $10.1159 / 000492614$

(c) 2018 The Author(s). Published by S. Karger AG, Basel www.karger.com/cnd

Yamabe et al.: Minimal Change Nephrotic Syndrome Relapse after 52 Years of Remission: A Case Report

\section{Introduction}

Minimal change nephrotic syndrome (MCNS) is a cause of nephrotic syndrome in approximately $90 \%$ of children aged $<10$ years, in $50-70 \%$ of older children, and in $10-15 \%$ of adults [1]. Although corticosteroid treatment is very effective, $85 \%$ of children with MCNS are steroid dependent and relapses are common after the reduction or discontinuation of corticosteroids. However, long-term remission can be expected in $75 \%$ of initial responders who do not relapse within 6 months [2]. Patients who relapse within 6 months become nonrelapsing after an average of 3 years, and $84 \%$ of these patients remain in long-term remission after 10 years [2]. In general, increasing the time since the last relapse reduces the risk of future relapses. Here, we report a very rare case of a patient who relapsed after 52 years of remission.

\section{Case Presentation}

A 61-year-old Japanese male visited our clinic with a pretibial edema which had already persisted for a few days. He did not show any symptoms suggestive of viral infection and did not have any chronic illness and allergic disease. He had a history of nephrotic syndrome that initially developed when he was 5 years old. His nephrotic syndrome was corticosteroid dependent, i.e., his urinary protein level rapidly reduced with corticosteroids, but relapses were common after the reduction or discontinuation of corticosteroids. He had not experienced a relapse since he was 9 years old. He could recall undergoing a renal biopsy but not its outcomes. Although his medical records were not available, we assumed that he had MCNS. He was not treated with immunosuppressive agents at that time because they were not available in Japan.

Physical examination revealed a pitting edema of his lower extremities (Fig. 1). His blood pressure was 176/100 $\mathrm{mm} \mathrm{Hg}$, his height was $169.8 \mathrm{~cm}$, and his weight was $72.0 \mathrm{~kg}$. The laboratory test results were as follows: hemoglobin, $14.9 \mathrm{~g} / \mathrm{dL}$; red blood cell count, $518 \times$ $10^{4} / \mathrm{mm}^{3}$; white blood cell count, 7,990/ $\mathrm{mm}^{3}$; platelet count, $28.9 \times 10^{4} / \mathrm{mm}^{3}$; total protein, $5.5 \mathrm{~g} / \mathrm{dL}$; serum albumin, $2.7 \mathrm{~g} / \mathrm{dL} ; \mathrm{Na}, 139 \mathrm{mEq} / \mathrm{L} ; \mathrm{K}, 4.2 \mathrm{mEq} / \mathrm{L} ; \mathrm{Cl}, 104 \mathrm{mEq} / \mathrm{L}$; serum creatinine, $0.92 \mathrm{mg} / \mathrm{dL}$; eGFR, $65.3 \mathrm{~mL} / \mathrm{min} / 1.73 \mathrm{~m}^{2}$; AST, $23 \mathrm{IU} / \mathrm{L} ; \mathrm{ALT}, 21 \mathrm{IU} / \mathrm{L}$; cholesterol, 318 $\mathrm{mg} / \mathrm{dL}$; triglyceride, $219 \mathrm{mg} / \mathrm{dL}$; blood glucose, $94 \mathrm{mg} / \mathrm{dL}$; and $\mathrm{HbA}_{1 \mathrm{c}} 5.4 \%$. Urinalysis showed urinary protein $3+$, negative glucose, and $5-9 / \mathrm{HPF}$ red blood cells in the sediment. The amount of urinary protein was $13.3 \mathrm{~g} / \mathrm{g}$ creatinine.

The patient was diagnosed with relapsed MCNS and was treated with $40 \mathrm{mg}$ of prednisolone, $40 \mathrm{mg}$ of furosemide, $75 \mathrm{mg}$ of spironolactone, and $20 \mathrm{mg}$ of azilsartan daily. In 1 week, his pretibial edema and urinary protein level reduced, and his blood pressure became normal. In 3 weeks, his serum total protein level was $6.1 \mathrm{~g} / \mathrm{dL}$ and his serum albumin level was 3.6 $\mathrm{g} / \mathrm{dL}$. Subsequently, furosemide and spironolactone were discontinued, and the dose of prednisolone was reduced. After 6 months, prednisolone was discontinued; no relapse has been noticed till now.

A renal biopsy was not performed because the proteinuria quickly responded to the corticosteroids, which is a characteristic of MCNS and is unusual in other causes of glomerulonephritis. 


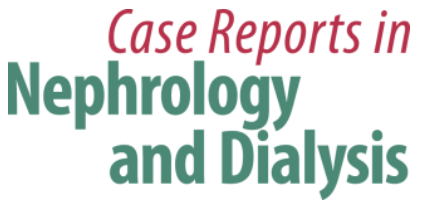

Case Rep Nephrol Dial 2018;8:178-181

DOI: $10.1159 / 000492614$

(c) 2018 The Author(s). Published by S. Karger AG, Basel www.karger.com/cnd

Yamabe et al.: Minimal Change Nephrotic Syndrome Relapse after 52 Years of Remission: A Case Report

\section{Discussion}

We experienced a rare case of MCNS that relapsed after 52 years of remission. MCNS is steroid dependent and usually relapses soon after dose reduction or discontinuation of corticosteroids. Habib and Kleinknecht [3] reported a relapse rate of $9 \%$ after 4 years of remission period and Cornfeld and Schwartz [4] reported a rate of $8.6 \%$ after 2 years of remission in children with MCNS. In adults with MCNS, the relapse rate is less than that in children with MCNS [4, 5]. The longer the period of remission, the lower the rate of relapse [5]. A patient who relapsed after 20 years of remission has previously been reported [6]. However, to the best of our knowledge, there are no other reports on patients who relapsed after 52 years of remission.

The reason underlying the relapse of the patient after 52 years of remission is unclear. The cause of MCNS remains uncertain, although a disorder of T lymphocytes may be involved [7].

MCNS occurs in some patients who take non-steroidal anti-inflammatory drugs (NSAIDs) and in patients with Hodgkin's disease. Our patient had not been prescribed NSAIDs and did not show any sign suggestive of Hodgkin's disease. It is possible that the occurrence of nephrotic syndrome at this time was unrelated to his childhood MCNS. However, this is unlikely because MCNS is a rare disease. Thus, we assumed that MCNS relapsed after 52 years of remission. Presently, we have no idea how to prevent additional relapses in such a rare case.

\section{Conclusions}

In summary, we describe a very rare case of MCNS that relapsed after 52 years of remission. In patients with nephrotic syndrome, clinicians should be aware of the possibility of a relapse even after a long period of remission.

\section{Statement of Ethics}

Written informed consent was obtained from the patient for publication of this case report.

\section{Disclosure Statement}

We have no conflicts of interest to declare.

\section{References}

1 Mason PD, Hoyer PF. Minimal change nephrotic syndrome. In: Floege J, Johnson RJ, Feehally J, editors. Comprehensive Clinical Nephrology. 4th ed. St. Louis: Elsevier Saunders; 2010. p. 218-27.

2 Tarshish P, Tobin JN, Bernstein J, Edelmann CM Jr. Prognostic significance of the early course of minimal change nephrotic syndrome: report of the International Study of Kidney Disease in Children. J Am Soc Nephrol. 1997 May;8(5):769-76.

3 Habib R, Kleinknecht C. The primary nephrotic syndrome of childhood. Classification and clinicopathologic study of 406 cases. Pathol Annu. 1971;6:417-74.

4 Cornfeld D, Schwartz MW. Nephrosis: long term study of children treated with corticosteroids. J Pediatr. 1966;68(4):507-15. 


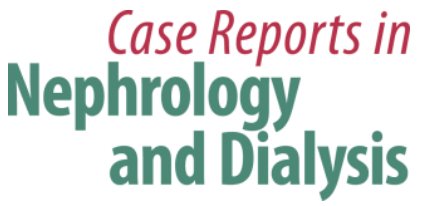

Case Rep Nephrol Dial 2018;8:178-181

DOI: $10.1159 / 000492614$

(c) 2018 The Author(s). Published by S. Karger AG, Basel www.karger.com/cnd

Yamabe et al.: Minimal Change Nephrotic Syndrome Relapse after 52 Years of Remission: A Case Report

5 Kida H, Iida H, Dohi K, Nakamoto Y, Mizumura Y, Takeuchi J. Period of freedom from relapse as an indication of cure in minimal change nephrotic syndrome in adults. Nephron. 1977;19(3):153-7.

6 Yoshimoto K, Wada T, Iwata Y, Sakai N, Shimizu M, Furuichi K, et al. A case of high-age minimal change nephrotic syndrome relapse after 18-year remission and effective treatment with steroid and cyclosporin combined therapy. Nihon Jinzo Gakkai Shi. 2000 Oct;42(8):640-3.

7 Moinuddin IK, Leehey DJ. Nephrotic syndrome. In: Moinuddin IK, Leehey DJ, editors. Handbook of nephrology. Philadelphia: Lippincott Williams \& Wilkins; 2013. p. 126-39.

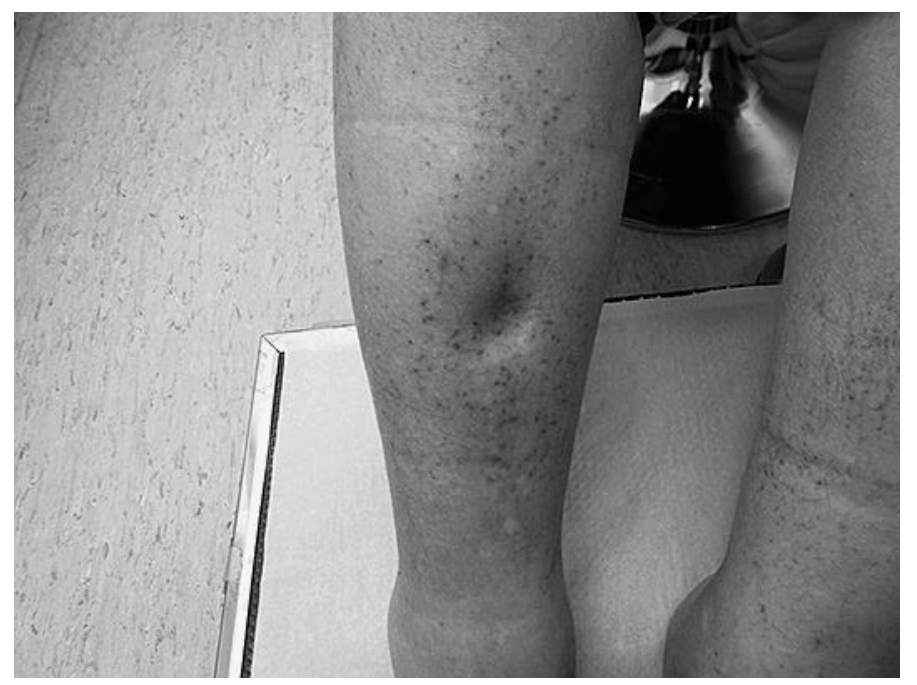

Fig. 1. Pitting edema of the patient's lower extremities was observed. 